\title{
Facultative feeding and consistency of trophic structure in marine soft-bottom macrobenthic communities
}

\author{
Tara A. Macdonald ${ }^{1,2, *}$, Brenda J. Burd ${ }^{3}$, Albert van Roodselaar ${ }^{4}$ \\ ${ }^{1}$ Institute of Ocean Sciences, Department of Fisheries and Oceans, 9860 West Saanich Rd., Sidney, British Columbia V8L 4B2, \\ Canada \\ ${ }^{2}$ Biologica Environmental Services, H-50 Nootka Court, 634 Humboldt St., Victoria, British Columbia V8W 1A4, Canada \\ ${ }^{2}$ Ecostat Research Limited, 1040 Clayton Road, N. Saanich, British Columbia V8L 5P6, Canada \\ ${ }^{3}$ Metro Vancouver, 4330 Kingsway, Burnaby, British Columbia V5H 4G8, Canada
}

\begin{abstract}
We investigated the roles of facultative versus strict niche feeding in the maintenance of trophic consistency in soft-bottom macrobenthic communities in the Strait of Georgia, British Columbia, Canada. Changes in trophic structure across gradients in depth and percent fine sediments were examined over a broad regional scale by identifying trophic compartment(s) responsible for the resulting trophic changes. The use of proportional organic biomass data allows direct comparison of community trophic structure across diverse hydrographic regime(s), large ranges in overall biomass and productivity, and highly variable community composition. Cluster analyses revealed low overall dissimilarity in trophic structure across all substrate and depth ranges (24 and $28 \%$ divergence, respectively), suggesting an overall economy of trophic function. Similarity percentage (SIMPER) analyses revealed that low trophic dissimilarity is driven primarily by the remarkably even distribution of the 2 dominant facultative feeding groups in all habitat types. These facultative groups contained the most ubiquitous and abundant taxa found throughout the Strait, and likely confer strong resilience in these communities to habitat change. In contrast, the small but significant divergences in trophic structure over depth and percent fine sediment gradients was explained by the distributions of strict niche feeders: (1) macro-omnivores and herbivores dependent on non-detrital food sources were important in shallow areas $(<25 \mathrm{~m})$ with coarse sediments $(<10 \%$ fine sediment), contributing to a unique trophic composition in these areas; and (2) subsurface deposit feeders were the only trophic group to vary significantly in proportional biomass explained by depth and percent fine sediment combined $(22 \%$; positive linear response to both factors).
\end{abstract}

KEY WORDS: Deposit feeding - Suspension feeding · Strait of Georgia · Salish Sea · British Columbia · Facultative feeding • Trophic structure

Resale or republication not permitted without written consent of the publisher

\section{INTRODUCTION}

Trophic dynamics within macrobenthic communities can drive carbon cycling and energy flow (Rhoads \& Young 1970, van Oevelen et al. 2006), contaminant cycling (Rakocinski et al. 1997), biogeochemical processes (Aller \& Yingst 1985, Desrosiers et al. 2000) and patterns of secondary production (Saiz-Salinas \& Ramos 1999) in marine soft-bottom ecosystems world- wide. In general, trophic composition is not thought to vary greatly or predictably across large regional scales (Gray 1981). This trophic consistency, if pervasive in soft-bottom communities, has ramifications for the relative ability of soft-bottom communities to withstand short-term or long-term habitat fluctuations.

Understanding of trophic dynamics within these communities is limited by knowledge of the feeding behaviour of many macrobenthic taxa (Pearson 
2001). Most studies of macrobenthic trophic structure tend to classify benthic fauna in terms of strictly defined trophic groups only (e.g. Chardy \& Clavier 1988, Gaston \& Nasci 1988, Ricciardi \& Bourget 1999, García-Arberas \& Rallo 2002, Coyle et al. 2007, Albano \& Obenat 2009, Cacabelos et al. 2009, Dolbeth et al. 2009). Most commonly these trophic groups are: suspension feeders, deposit feeders (surface and subsurface), carnivores, herbivores and omnivores. However, many macrobenthic taxa exhibit more than one feeding mode (e.g. Okamura 1990, Brown et al. 2000, Gaudencio \& Cabral 2007, Gray \& Elliott 2009). This trophic flexibility has been proposed as an important feature of benthic marine communities (Cadée 1984). For instance, many species of facultatively carnivorous polychaetes are also known to deposit feed (e.g. Glyceridae, members of Lumbrineridae; Fauchald \& Jumars 1979). Other taxa use combinations of suspension and deposit feeding (e.g. spionid polychaetes [Taghon et al. 1980, Dauer et al. 1981]; chaetopterid polychaetes [Busby \& Plante 2007]; tellinid bivalves [Pohlo 1969, Levinton 1991, Rossi et al. 2004]; nuculid bivalves [Rhoads 1974]; and thyasirid bivalves [Word 1990]). These facultatively feeding animals are presumably able to vary their diet with local food availability, thus adding further resilience to the community in response to habitat changes. Few trophic studies explicitly consider this facultative feeding behaviour (but see Gaudencio \& Cabral 2007).

The quantitative assessment of facultative versus strict feeding guilds is crucial to the understanding of shifts in macrobenthic trophic structure over habitat gradients, particularly across regions with considerable variability in faunal composition, total abundance and total biomass. In addition, although background benthic communities may change in composition and dominance over time in any particular habitat type, we hypothesize that trophic structure of these communities changes over time only when food supply changes. When one species declines, another species fills the gap. Thus we predict trophic consistency with stable food supply. However, when food supplies change, how rapidly and efficiently can the communities adapt? The response may depend largely on facultative feeding, or the ability of endemic species to switch feeding modes as required. Facultative feeding may therefore be a crucial factor in explaining why some taxa are ubiquitous and abundant over broad coastal regions, and by extrapolation, how variable and stable the habitat types are in that region.

Understanding how trophic structure may change in response to extreme habitat change due to factors such as anthropogenic discharges first requires understanding changes over natural habitat gradients. Past studies found that trophic structure in marine habitats responds to depth gradients (e.g. Dolbeth et al. 2009, Gaudencio \& Cabral 2007, Bergmann et al. 2009) and substrate type (i.e. silt and/or clay content) (e.g. Sanders 1958, Rhoads \& Young 1970, Levinton 1972, Rhoads 1974, Pearson \& Rosenberg 1987, Ricciardi \& Bourget 1999, García-Arberas \& Rallo 2002, Levinton \& Kelaher 2004). However, it remains unclear whether these responses are driven by large-scale changes in the whole community or by a few dominant feeding groups (e.g. facultative feeders or niche-feeders) or specific taxa. Thus, it is imperative to not only clarify the factors that shape trophic function of macrobenthic communities, but also evaluate the relative importance of facultative versus niche feeding among communities across wide variations in habitat. This knowledge will aid in understanding how facultative feeding allows benthic communities to adapt to rapid as well as gradual habitat changes.

The regional database for the Strait of Georgia, Salish Sea, British Columbia, Canada, described in Burd et al. (2008a, 2009), provides an opportunity to assess trophic consistency and flexibility of benthic communities across a hydrographically complex coastal sea (Hill et al. 2008). In the present study, we address the following questions: (1) how much and in what specific trophic compartments does benthic faunal structure vary over a broad geographic and habitat range, and (2) what is the relative importance of facultative versus specific niche feeding in the functioning and stability of marine benthic communities in the Strait?

\section{MATERIALS AND METHODS}

\section{Description of database}

The Strait of Georgia database consists of benthic macrofaunal and related habitat data from areas not directly under the influence of localized anthropogenic inputs (termed here as 'background' locations; Burd et al. 2008a) ( $\mathrm{n}=1167$ samples; see Fig. 1 for general sampling locations). This database is updated and maintained at the Institute of Ocean Sciences, Sidney, British Columbia (Fisheries and Oceans Canada).

The background biological and associated sediment data were collected from grab samples taken during monitoring programs, impact assessments, or as part of the Strait of Georgia collaborative research 


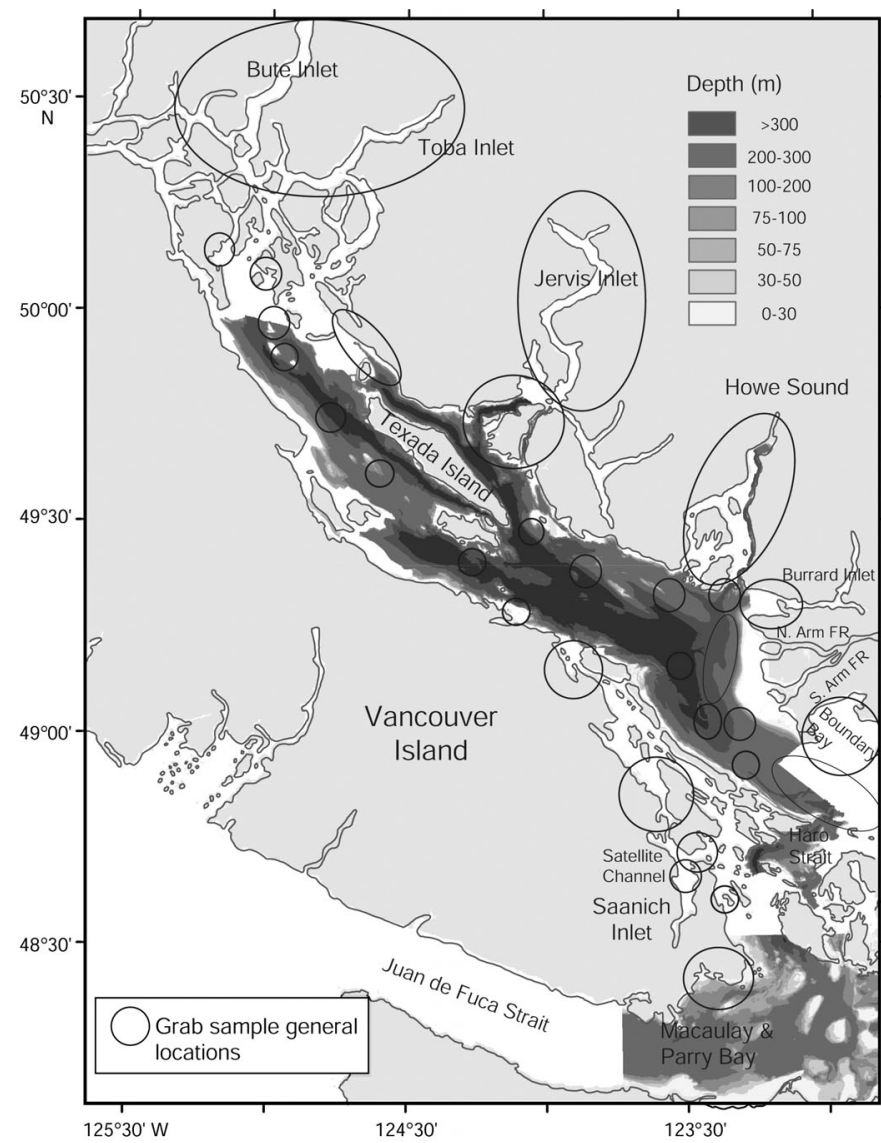

Fig. 1. General locations (circles and ellipses) of macrobenthic grab sampling surveys compiled in the Strait of Georgia database (coastal British Columbia, Canada)

project (involving Metro Vancouver, Fisheries and Oceans Canada, and Natural Resources Canada); Johannessen et al. 2008). The database contains samples compiled from the past $25 \mathrm{yr}$, although the majority of the samples (941 of 1167) were collected over the past $10 \mathrm{yr}$.

All biological samples were collected using a $0.1 \mathrm{~m}^{2}$ grab (Van Veen or Smith-MacIntyre), screened on $1 \mathrm{~mm}$ sieves, initially preserved in 4 to $10 \%$ formalin and transferred to 70 to $95 \%$ ethanol for processing. All taxa were identified to species, or to the lowest possible taxonomic level. Although the same technicians and taxonomists did not process all samples, all surveys followed strict quality control. A detailed coding system maintained taxonomic consistency across studies (Macdonald et al. 2010). All grab samples have associated data on depth (1 to $678 \mathrm{~m}$ ) and percent fine sediments (silt and clay, particles $<65 \mu \mathrm{m}$ in diameter; 0.1 to $99 \%$ ).

We collected species-specific wet mass biomass estimates exclusively on preserved specimens. Any biomass shrinkage related to this preservation method (e.g. Gaston et al. 1996, Wetzel et al. 2005) should be consistent, and we examine only relative biomass proportions. Biomass estimates represent species-specific mean masses for a range of sizes collected concurrently with initial processing of the samples for the majority of the database. Separate biomass estimates for both 'adults' and 'subadults' give more accurate estimates of total biomass. Remaining biomass estimates are based on mean species masses from historical reference collections. We converted wet mass biomass values into organic biomass using taxon-specific conversions (Brey 2001, B. J. Burd unpubl. data) to remove the different contributions of hard parts of various taxa (e.g. shells in bivalves, endoskeletons of echinoderms).

\section{Trophic categorization}

Macdonald et al. (2010) compiled available information on the feeding and behaviour of all macrobenthic taxa in the database, based on an extensive literature survey. When literature data were unavailable, information on feeding modes and behaviour was collected via consultation with taxonomic experts (Biologica Environmental Services Ltd, Victoria, BC) and microscopic examination of feeding structures and observations of behaviour in the laboratory. When these avenues were exhausted, taxa were categorized according to the feeding mode(s) of closely related taxa. The following categorization (see Table 1) streamlines the detailed information available in Macdonald et al. (2010) and delineates taxa with clearly defined, strict niche-feeding regimes and taxa that are facultative (i.e. known to exhibit more than one mode of feeding). The categorization is similar to that of Gaudencio \& Cabral (2007).

Table 1 summarizes trophic categories. Animals with 'strict' feeding regimes, or those that appear to feed exclusively in one niche are: (1) suspensivores, feeding exclusively from the water column; (2) surface deposit feeders, collecting and ingesting particles from the sediment surface; (3) subsurface deposit feeders, which feed head-down in the sediments, ingesting particles from below the sediment surface (often with respiratory appendages on their posterior end); (4) herbivores, feeding exclusively on microalgae and macroalgae; (5) planktivorous carnivores, feeding on zooplankton; (6) benthic carnivores, feeding on meiofauna or macrofauna; and (7) macro-omnivores, which feed on large particulate matter in a raptorial fashion and are not known to have a detrital component to their diet. Rare feeding 
Table 1. Trophic classification of macrobenthic taxa in the Strait of Georgia, with examples. Dominant trophic groups are in bold

\begin{tabular}{|c|c|c|c|c|}
\hline $\begin{array}{l}\text { Feeding group } \\
\text { (abbreviation) }\end{array}$ & $\overline{\text { Taxa }}$ & $\begin{array}{l}\text { Jo. of }- \\
\text { Samples }\end{array}$ & $\begin{array}{c}\text { Proportion of organic } \\
\text { biomass, mean } \pm \text { SE (SD) }\end{array}$ & Examples of dominant taxa \\
\hline Suspensivores (SU) & 242 & 783 & $0.036 \pm 0.003(0.008)$ & $\begin{array}{l}\text { Ascidiacea, Porifera, Brachipoda, Bryozoa, } \\
\text { Protothaca staminea, Solen sicarius } \\
\text { (Bivalvia), Megalomma splendida, Myxi- } \\
\text { cola infundibulum (Annelida) }\end{array}$ \\
\hline Surface deposit feeders (SRD) & 286 & 1096 & $0.103 \pm 0.001(0.141)$ & $\begin{array}{l}\text { Chirodota albatrossi (Holothuroidea), } \\
\text { Pinnixa occidentalis (Brachyura), Pista wui, } \\
\text { Ampharete acutifrons (Annelida), Lirobit- } \\
\text { tium minutum (Gastropoda) }\end{array}$ \\
\hline Subsurface deposit feeders (SSD) & 137 & 1062 & $0.281 \pm 0.003(0.214)$ & $\begin{array}{l}\text { Molpadia intermedia (Holothuroidea), } \\
\text { Brisaster latifrons (Echinoidea), Travisia } \\
\text { pupa, Maldanidae, Sternaspidae, } \\
\text { Capitellidae (Annelida) }\end{array}$ \\
\hline Herbivores (HE) & 41 & 148 & $0.005 \pm 0.001(0.015)$ & $\begin{array}{l}\text { Idoteidae (Isopoda), Strongylocentrotus } \\
\text { spp. (Echinoidea), Littorinidae (Gastro- } \\
\text { poda), Amphthoidae (Amphipoda) }\end{array}$ \\
\hline Planktivorous carnivores (PC) & 86 & 701 & $0.008 \pm 0.002(0.046)$ & $\begin{array}{l}\text { Pachycerianthus fimibriatus, Pennatulidae } \\
\text { (Anthozoa), Bougainvilliidae (Hydroida), } \\
\text { Eusiridae (Amphipoda) }\end{array}$ \\
\hline Benthic carnivores (BC) & 333 & 1047 & $0.042 \pm 0.003(0.084)$ & $\begin{array}{l}\text { Nemertea, Phyllodoce groenlandica, } \\
\text { Pholoidae, Aphroditidae (Annelida), } \\
\text { Naticidae, Nassariidae (Gastropoda) }\end{array}$ \\
\hline Macro-omnivores (OM) & 42 & 358 & $0.025 \pm 0.005(0.088)$ & $\begin{array}{l}\text { Cancridae (Brachyura), Paguridae } \\
\text { (Anomura), Onuphidae (Annelida) }\end{array}$ \\
\hline Facultative detritivores (FD) & 300 & 1093 & $0.385 \pm 0.006(0.204)$ & $\begin{array}{l}\text { Thyasiridae, Tellindae, Nuculidae, } \\
\text { Yoldiidae (Bivalvia), Ophiuroidea (most), } \\
\text { Spionidae, Chaetopteridae, Oweniidae } \\
\text { (Annelida) }\end{array}$ \\
\hline Facultative carnivores (FC) & 252 & 1094 & $0.171 \pm 0.003(0.132)$ & $\begin{array}{l}\text { Glyceridae, Goniadidae (Annelida), } \\
\text { Lumbrineridae (Annelida), Cylichnidae } \\
\text { (Gastropoda), Astyris gausapata (Gastro- } \\
\text { poda), Scaphopoda }\end{array}$ \\
\hline
\end{tabular}

groups include parasites, lignivores and taxa that rely on chemosynthetic symbionts. Parasites are included with carnivores (either benthic or planktivorous, depending on their host). The remaining feeding groups, which are rare or limited to very specific habitat conditions unlikely to occur in background subtidal sediments (lignivores and chemosymbiotic taxa), contribute little to overall biomass and occur in only a subset of samples and are thus not included here. Animals known to occur in facultative association with chemosynthetic bacteria (e.g. thyasirid bivalves; Dufour \& Felbeck 2006) are included in their principal feeding category.

We consider the remaining 2 trophic groups (Table 1) to be facultative, because they appear to utilize different feeding modes or resources under different conditions. These groups are: (1) facultative detritivores, which may feed as suspensivores, surface deposit feeders or subsurface deposit feeders; and (2) facultative carnivores, which feed as preda- tors or scavengers on macrofauna or meiofauna, but also deposit feed.

\section{Multivariate analyses}

Over the entire Strait of Georgia, because body sizes of organisms in each trophic group vary greatly, mean size of organisms generally increases with depth and total abundance, and biomass of macrobenthos declines with depth (Burd et al. 2008a), it is most appropriate to use proportional organic biomass data for assessments of trophic structure. This strategy standardizes trophic structure comparisons over many different faunal communities and habitat types.

For the purposes of simplicity in analysis and interpretation, we condensed depth and substrate type into categorical ranges. We categorized percentage of fine sediments (fines) as: (1) $0-10 \%$ ( $\mathrm{N}=58)$, (2) $11-20 \%(\mathrm{~N}=31),(3) 21-30 \% \quad(\mathrm{~N}=1020)$, 
(4) $31-50 \%(\mathrm{~N}=250)$, (5) $51-85 \%(\mathrm{~N}=294)$ and (6) $86-100 \%(\mathrm{~N}=433)$; and depth as (1) $1-10 \mathrm{~m} \mathrm{(N=}$ 75), (2) $11-25 \mathrm{~m}(\mathrm{~N}=66)$, (3) $26-50 \mathrm{~m}(\mathrm{~N}=134)$, (4) 51-99 m ( $\mathrm{N}=650),(5) 100-200 \mathrm{~m}(\mathrm{~N}=63)$ and (6) $>201 \mathrm{~m}(\mathrm{~N}=180)$. We used multivariate analyses to evaluate the following null hypotheses:

$H_{01}$ : Macrobenthic trophic structure is similar among depth categories;

$H_{02}$ : Macrobenthic trophic structure is similar across sediment categories.

We compared trophic structure by comparing pairwise Bray-Curtis (Bray \& Curtis 1957) dissimilarities of the proportional trophic composition of all depth or sediment categories. For ease of interpretation, we ran analyses separately for depth and sediment composition to test for significant variations in trophic structure. We grouped clusters from the matrix of pair-wise similarities using an agglomerative, hierarchical sorting procedure (unweighted pair group mean average sort) (Sneath \& Sokal 1973). Using the replicate sample data for each category, a statistical bootstrap method called SIGTREE (Nemec \& Brinkhurst 1988) generated multiple simulations to test the generalized null hypotheses $\left(H_{01}\right.$ and $\left.H_{02}\right)$ at each cluster linkage that 2 categories (depth or fines) were homogeneous (not significantly different). The method is non-parametric, and makes no assumptions about the underlying distribution of the multivariate data. The method examines the relative variability within and between station groups independently for each linkage, to determine whether a cluster grouping is statistically valid at a pre-determined probability level (alpha) of $\mathrm{p}<0.01$ (for 6 sample categories in each analysis, overall potential type I error or alpha $=$ 0.06 for each analysis).

In order to clarify which trophic groups drive these similarity patterns, we used similarity percentage (SIMPER) analysis in PRIMER (Clarke \& Warwick 2001). SIMPER analyses (Clarke \& Gorley 2006) assess which trophic groups dominate in each depth or sediment category through pairwise comparisons of the percentage contributions of each trophic group to the overall Bray-Curtis similarity in those habitat categories. A 2-way SIMPER analysis assessed depth and sediment category simultaneously, although this procedure does not account for the interaction between them.

We expect that depth and sediment category are likely not independent habitat factors. Therefore, we assessed the contribution of individual trophic groups to observed patterns in trophic structure using multiple linear regressions (Wessa 2011). For each trophic group, we analyzed the variability in proportional biomass using a 2 -factor (depth and percent fine sediment) multiple regression to determine the variance of a given trophic group explained by both depth and percent fine sediment. Given that regressions are based on continuous data, we used the original depths and percent fines values from the database. This strategy has the added benefit of examining whether the arbitrary categorization of depths and percent fines in the SIGTREE and SIMPER analyses affected resulting cluster patterns.

\section{RESULTS}

Most of the Strait of Georgia samples were collected from depths $<250 \mathrm{~m}$ (Fig. 2), which reflects the general depth range for most of the main basin except the deeper surrounding fjords. Depth ranges used for each category were not equal, partly to allow reasonable samples sizes for each depth category, and partly because habitat types and drivers were relatively homogeneous below $200 \mathrm{~m}$ in the Strait (Burd et al. 2008a, b). Substrate percent fines ranged from 0 to $100 \%$ at depths $<100 \mathrm{~m}$, and the coarsest sediments rarely occurred below this depth.

Four trophic groups dominated proportional biomass (Table 1): facultative detritivores, facultative carnivores, surface deposit feeders and subsurface deposit feeders. These groups alone contributed $>10 \%$ of mean organic biomass across all samples. The remaining trophic groups each encompassed an average of $<5 \%$ of mean organic biomass across all samples.

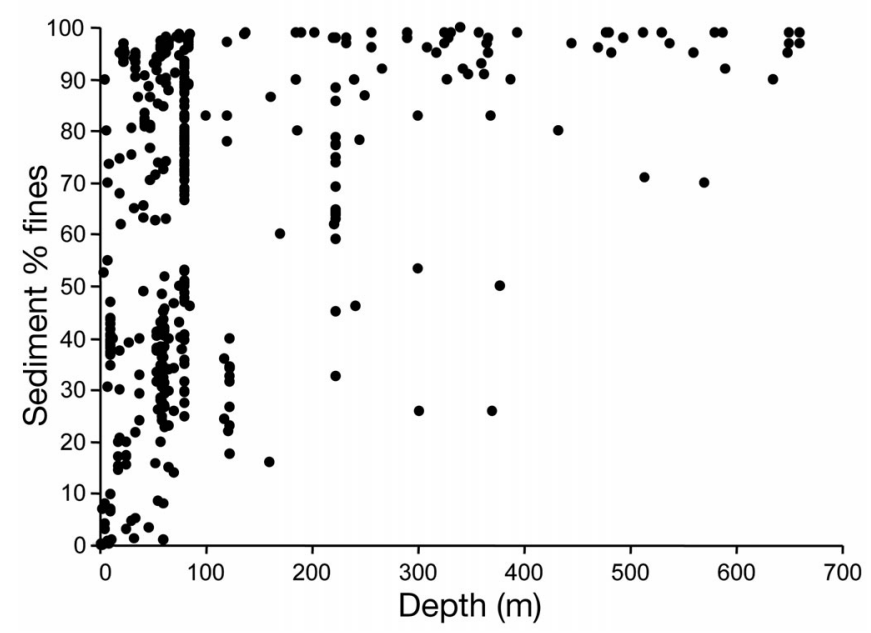

Fig. 2. Distribution of grab samples in the Strait of Georgia background database across depth and percent fines (silt and clay) gradients 
Because Bray-Curtis similarities are sensitive to high dominance (see Table 1), all analyses were repeated using different data transformations (e.g. $\log$, fourth-root and arcsin) to decrease the influence of the dominant trophic groups, or to stabilize variability related to the use of proportional biomass data. However, none of the data transformations noticeably affected results. Therefore, the following results are all based on proportional biomass of trophic groups, without transformations.

Overall trophic similarity was high across all depth and sediment categories. The maximum Bray-Curtis dissimilarity for trophic structure based on proportional biomass was $<0.3$ for all depth and percent fine sediment categories $(0.24$ for depth and 0.28 for percent fine sediment; Fig. 3a,b, respectively). However, trophic structure varied significantly over sediment and depth gradients.

The cluster groupings for percent fines categories (Fig. 3a) show a clear gradient in trophic structure. Significantly distinct groupings at $\mathrm{p}<0.01$ include: (1) $0-10 \%$ fines, (2) $11-20$ and $21-30 \%$ fines, (3) $31-50 \%$ fines, (4) $51-85 \%$ fines and (5) $86-100 \%$ fines.
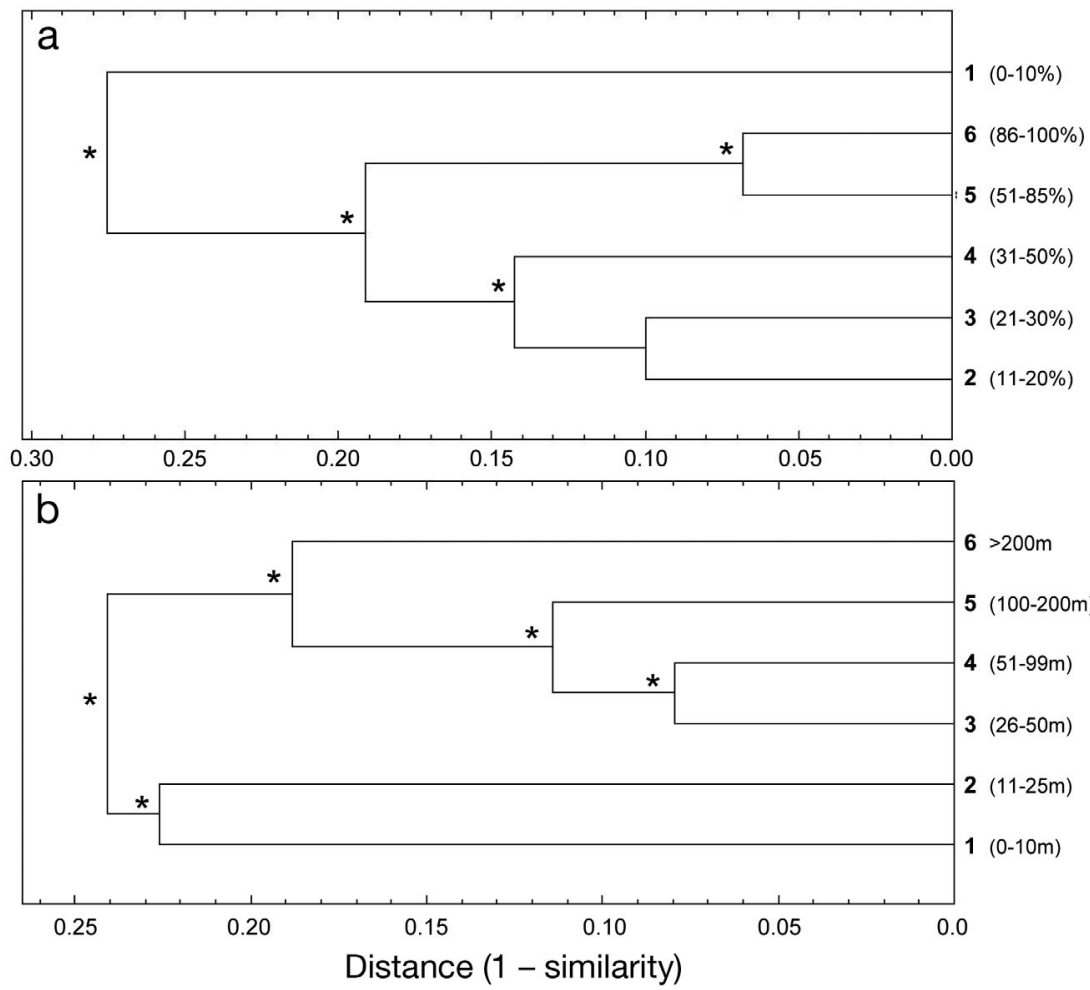

Fig. 3. Results from SIGTREE analyses showing trophic structure based on proportional organic biomass $(\mathrm{kJ})$ across (a) percent fine sediment and (b) depth categories (indicated by numerals; see Table 2). Asterisks indicate rejection of the null hypothesis (at $\alpha=0.01$ ) that the 2 groups being linked are homogeneous

The most dissimilar trophic structure occurred in coarse sediments $(<10 \%$ fines; Fig. 3a). Samples from categories of $>50 \%$ fines were similar in trophic structure, despite considerable variation in depth (0-678 m; Fig. 2). Samples with $11-50 \%$ fines were also similar in trophic structure, but limited to a narrower and shallower depth range.

The cluster groupings for depth categories (Fig. 3b) show a clear gradient in trophic structure with depth, with significantly different depth categories. The most dissimilar trophic structure occurred at depths $<25 \mathrm{~m}$ (Fig. 3b), in spite of a wide range in fine sediments (Fig. 2). Samples $>200 \mathrm{~m}$ (Category 6) formed the next most dissimilar grouping, and had more consistently fine sediments than the shallower groupings.

The 2-way SIMPER analysis (Table 2) shows that the 4 dominant trophic groups (facultative detritivores, facultative carnivores, surface deposit feeders and subsurface deposit feeders) tended to drive trophic similarity within habitat categories. However,

other groups were important in some depth or fine sediment categories. For instance, macro-omnivores were important contributors to the trophic structure in sediments with $11-20 \%$ fines from 11 to $25 \mathrm{~m}$ depth. Suspensivores were most important at depths $<10 \mathrm{~m}$ and in sediments with $<50 \%$ fines. Benthic carnivores contributed weakly, but consistently, to trophic structure throughout all depth and sediment ranges.

Multiple regression analyses show that variability in proportional organic biomass of most trophic groups was not driven by depth or substrate type (Table 3), with 2 exceptions: significant variability in herbivore proportional biomass was related to depth; in addition, biomass variability in subsurface deposit feeders was related to both depth and percent fines. The individual responses of dominant trophic groups to depth and sediment are described below.

Facultative detritivores (Fig. 4a) were fairly evenly distributed across sediment and depth categories, with a slight decrease in mean proportional biomass below depths of $100 \mathrm{~m}$. This trophic group contributed significantly to overall trophic consistency 
Table 2. Two-way SIMPER analysis for categories of depth and percent fine sediment (fines). Percentages are the contribution of trophic groups to Bray-Curtis similarity. See Table 1 for trophic group abbreviations. Additional minor contributing trophic groups are not shown. N-values are the number of samples assigned to the indicated habitat categories

\begin{tabular}{|c|c|c|c|c|c|c|c|c|c|}
\hline & & - Depth- & & & & $\mathrm{Pe}$ & ercent fine & & \\
\hline $\begin{array}{l}\text { Depth } \\
\text { category }\end{array}$ & $\begin{array}{l}\text { Depth } \\
\text { range }(\mathrm{m}) \\
(\mathrm{N})\end{array}$ & $\begin{array}{l}\text { Overall } \\
\text { similarity } \\
(\%)\end{array}$ & $\begin{array}{l}\text { Trophic } \\
\text { group }\end{array}$ & $\begin{array}{c}\text { Contribution to } \\
\text { within-group } \\
\% \text { similarity } \\
\text { (cumulative) }\end{array}$ & $\begin{array}{l}\text { Sediment } \\
\text { category }\end{array}$ & $\begin{array}{l}\text { Percent } \\
\text { fines } \mathrm{s} \\
(\mathrm{N})\end{array}$ & $\begin{array}{l}\text { Overall } \\
\text { similarity } \\
(\%)\end{array}$ & $\begin{array}{c}\text { Trophic } \\
\text { group }\end{array}$ & $\begin{array}{c}\text { Contribution to } \\
\text { within-group } \\
\% \text { similarity } \\
\text { (cumulative) }\end{array}$ \\
\hline 1 & $0-10(75)$ & 59.1 & FD & 58 & 1 & $0-10(58)$ & 55.5 & FD & 62.3 \\
\hline & & & SSD & $18.5(76.5)$ & & & & $\mathrm{FC}$ & $17.0(79.3)$ \\
\hline & & & $\mathrm{FC}$ & $13.5(90.0)$ & & & & SSD & 7.5 (86.8) \\
\hline & & & SRD & $4.8(94.8)$ & & & & $\mathrm{BC}$ & $5.2(92.0)$ \\
\hline & & & $\mathrm{BC}$ & $3.4(98.2)$ & & & & SRD & $4.7(96.7)$ \\
\hline & & & SU & $1.6(99.8)$ & & & & $\mathrm{SU}$ & $3.0(99.7)$ \\
\hline 2 & $11-25(66)$ & 57.7 & FD & 53.3 & 2 & $11-20(31)$ & 54.6 & $\mathrm{FD}$ & 49 \\
\hline & & & $\mathrm{FC}$ & $13.2(66.5)$ & & & & OM & $16.0(65.1)$ \\
\hline & & & $\mathrm{OM}$ & $12.0(78.5)$ & & & & $\mathrm{FC}$ & $14.6(79.7)$ \\
\hline & & & SRD & $10.6(89.1)$ & & & & SSD & $9.3(89.0)$ \\
\hline & & & SSD & $7.0(96.1)$ & & & & SRD & $5.5(94.5)$ \\
\hline & & & $\mathrm{BC}$ & $3.1(99.2)$ & & & & $\mathrm{BC}$ & $4.2(98.7)$ \\
\hline & & & & & & & & SU & $1.3(100.0)$ \\
\hline 3 & $26-50(134)$ & 76.1 & FD & 46.9 & 3 & $21-30(102)$ & 63.9 & FD & 46.2 \\
\hline & & & SSD & $27.2(74.1)$ & & & & $\mathrm{FC}$ & $15.9(62.0)$ \\
\hline & & & FC & 19.1 (93.1) & & & & SRD & $14.4(76.4)$ \\
\hline & & & SRD & $4.8(97.9)$ & & & & SSD & $14.3(90.7)$ \\
\hline & & & $\mathrm{BC}$ & $1.5(99.4)$ & & & & $\mathrm{SU}$ & $5.6(96.3)$ \\
\hline & & & & & & & & $\mathrm{BC}$ & $3.1(99.4)$ \\
\hline 4 & $51-100(650)$ & 73.5 & FD & 43.5 & 4 & $31-50(250)$ & 71.7 & FD & 52.3 \\
\hline & & & SSD & $31.1(74.6)$ & & & & $\mathrm{FC}$ & $19.4(71.7)$ \\
\hline & & & $\mathrm{FC}$ & $16.5(90.9)$ & & & & SSD & $17.0(88.7)$ \\
\hline & & & SRD & $5.5(96.6)$ & & & & SRD & $4.5(93.3)$ \\
\hline & & & $\mathrm{BC}$ & $2.0(98.6)$ & & & & $\mathrm{SU}$ & $2.9(96.2)$ \\
\hline & & & $\mathrm{SU}$ & $1.1(99.7)$ & & & & $\mathrm{BC}$ & 2.7 (98.9) \\
\hline & & & & & & & & $\mathrm{PC}$ & $0.7(99.6)$ \\
\hline 5 & $101-200(63)$ & 60.8 & SSD & 38.5 & 5 & $51-85$ (294) & 71.8 & SSD & 39.9 \\
\hline & & & $\mathrm{FD}$ & $29.2(67.7)$ & & & & $\mathrm{FD}$ & 38.7 (78.6) \\
\hline & & & $\mathrm{FC}$ & $20.7(88.4)$ & & & & $\mathrm{FC}$ & $14.1(92.7)$ \\
\hline & & & SRD & 6.9 (95.3) & & & & SRD & $4.4(97.1)$ \\
\hline & & & $\mathrm{BC}$ & $2.7(98.0)$ & & & & $\mathrm{BC}$ & $2.5(99.6)$ \\
\hline & & & $\mathrm{SU}$ & $1.3(99.3)$ & & & & & \\
\hline 6 & $>201$ (180) & 45.7 & SSD & 36.8 & 6 & $86-100(433)$ & 67.3 & FD & 38.6 \\
\hline & & & FD & $25.7(62.5)$ & & & & SSD & $35.3(73.9)$ \\
\hline & & & SRD & $19.1(81.6)$ & & & & $\mathrm{FC}$ & $16.0(89.9)$ \\
\hline & & & $\mathrm{FC}$ & $16.0(97.6)$ & & & & SRD & $8.4(98.3)$ \\
\hline & & & $\mathrm{BC}$ & $2.3(99.9)$ & & & & $\mathrm{BC}$ & $1.5(99.8)$ \\
\hline
\end{tabular}

across depth and sediment gradients (Table 2), although their importance diminished in deep samples with fine sediments, where subsurface deposit feeders begin to dominate (Table 2).

Facultative carnivores contributed between 13 and $19 \%$ to trophic similarity across all depth and sediment categories (Table 2) and varied little among categories (Fig. 4B), suggesting that their distributions were not influenced by these habitat variables, as echoed in regression analyses (Table 3).
Only subsurface deposit feeders responded significantly to both depth $\left(\mathrm{R}^{2}=0.12\right.$; Table 3$)$ and substrate type $\left(\mathrm{R}^{2}=0.15\right)$. Analysis of these variables together in a multiple regression improved the fit of this model $\left(\mathrm{R}^{2}=0.22\right.$; Table 2$)$. The proportional biomass of this feeding group increased at $>50 \%$ fines and $>100 \mathrm{~m}$ depth (Fig. 4C).

Surface deposit feeders did not respond in a linear fashion to depth or substrate type (Table 3), but did contribute significantly to trophic similarity in some 
Table 3. Response of trophic group proportional biomass to depth and percent fine sediment (fines). Multiple and single regressions were linear. Trophic groups in bold show evidence of a response in their proportional biomass to depth, percent fine sediment, or both

\begin{tabular}{|lccccccc|}
\hline \multirow{2}{*}{ Trophic group } & \multicolumn{3}{c}{ Multiple } & \multicolumn{4}{c}{ Single regression } \\
& regression & \multicolumn{2}{c|}{$\begin{array}{c}\text { Depth } \\
\text { Percent fines }\end{array}$} \\
& $\mathrm{R}^{2}$ & $\mathrm{p}$ & $\mathrm{R}^{2}$ & $\mathrm{p}$ & $\mathrm{R}^{2}$ & $\mathrm{p}$ \\
\hline Facultative detritivores & 0.03 & 0 & 0.02 & 0 & 0.03 & 0 \\
Facultative carnivores & 0.00 & 0.4 & 0.00 & 0.89 & 0.00 & 0.30 \\
Subsurface deposit feeders & $\mathbf{0 . 2 2}$ & $\mathbf{0}$ & $\mathbf{0 . 1 2}$ & $\mathbf{0}$ & $\mathbf{0 . 1 5}$ & $\mathbf{0}$ \\
Surface deposit feeders & 0.06 & 0 & 0.06 & 0 & 0.02 & 0 \\
Suspensivores & 0.07 & 0 & 0.05 & 0 & 0.05 & 0 \\
Macro-omnivores & 0.08 & 0 & 0.08 & 0 & 0.02 & 0.04 \\
Benthic carnivores & 0.02 & 0.01 & 0.00 & 0.49 & 0.02 & 0 \\
Planktivorous carnivores & 0.03 & 0 & 0.02 & 0.01 & 0.00 & 0.85 \\
Herbivores & $\mathbf{0 . 2 1}$ & $\mathbf{0}$ & $\mathbf{0 . 2 0}$ & $\mathbf{0}$ & $\mathbf{0 . 0 9}$ & $\mathbf{0}$ \\
\hline
\end{tabular}
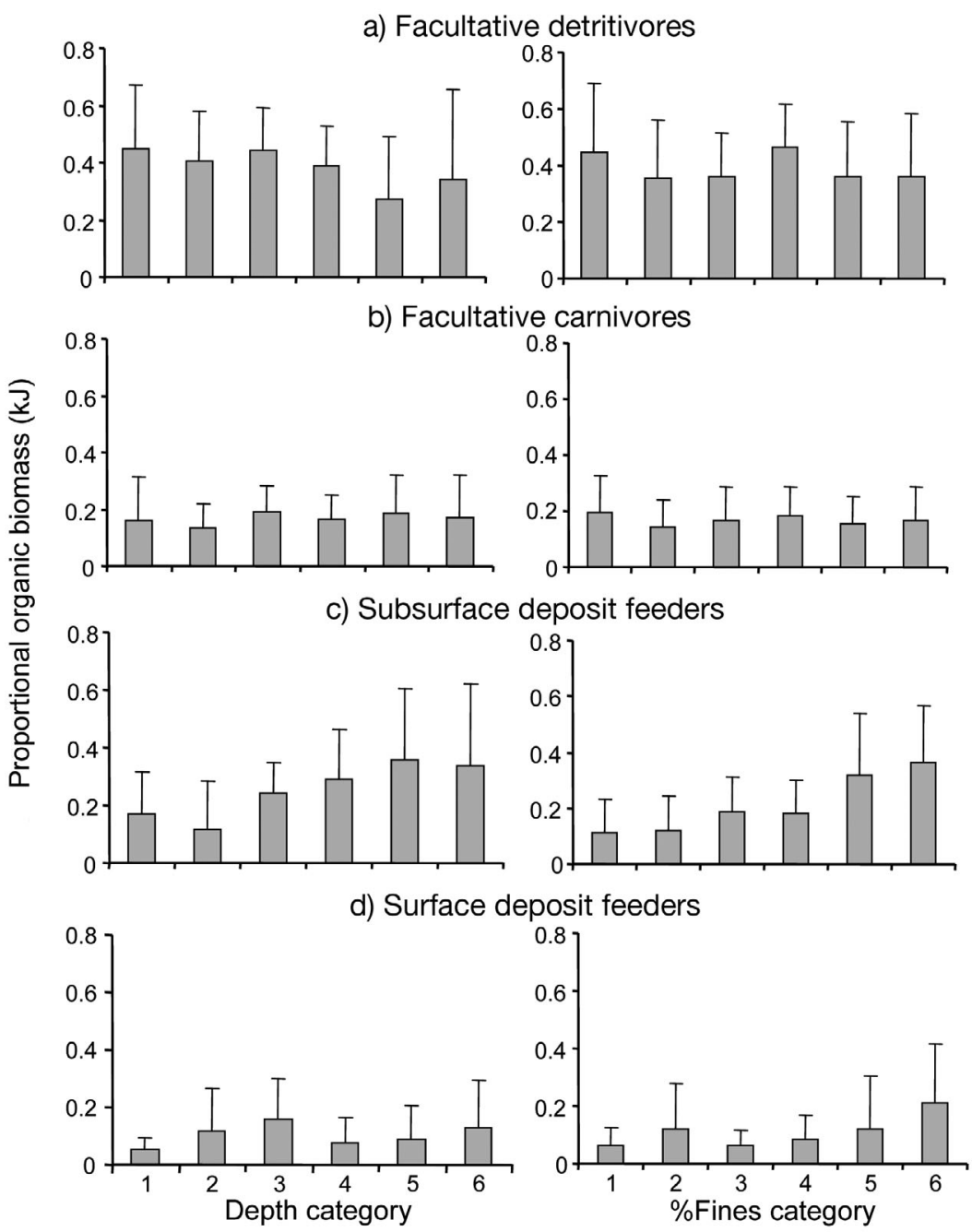

Fig. 4. Proportional organic biomass (kJ) of the 4 dominant trophic groups in the Strait of Georgia, British Columbia, across depth categories (left column) and percent fine sediment (fines) categories (right column): (a) facultative detritivores, (b) facultative carnivores, (c) subsurface deposit feeders and (d) surface deposit feeders. Means + SD. See Table 2 for sample sizes, percent fine sediment and depth categories samples (Table 2), though their proportional contribution to total biomass was highest in samples with coarse sands (11-30\% fines) from deep locations (>200 m; Fig. 4d).

Macro-omnivores appeared to have relatively narrow habitat requirements, accounting for $16 \%$ of overall similarity in fines Category 2 (11-20\% fine sediments) and $12 \%$ of trophic similarity in depth Category 2 (11$25 \mathrm{~m}$ ) (Table 2). This result was expected given that this group feeds primarily on large detrital debris that likely derives from macroalgae or seagrass within this depth range or from up-shore areas. Because of this narrow habitat requirement, they do not show a linear response to either depth or percent fines.

Benthic carnivores were evenly distributed across all habitats, contributing $1.5-5 \%$ of trophic similarity across all depth and sediment categories (Table 2). This pattern suggests that although this trophic group contributed little to total biomass, it is an important and ubiquitous group in all Strait of Georgia subtidal sediments.

Suspensivores contributed between 1 and $6 \%$ of trophic similarity in sediments with substantial sand content ( $<50 \%$ fines) in some depths up to $200 \mathrm{~m}$ (Table 2). However, the lack of a significant response to either depth or percent fine sediment (Table 3) indicates that the proportional biomass of this group was unaffected by gradations in substrate type or depth within this habitat range.

Herbivores, which are typically found within the photic zone, are expected to respond to depth (Table 3), but were such a minor component of the food web that they did not affect trophic structure (Table 2).

Planktivorous carnivores did not contribute notably to overall biomass, influence trophic structure across depth and percent fine sediment categories, or vary significantly with either habitat factor. 


\section{DISCUSSION}

The potential for large-scale changes in benthic marine communities associated with climate change coupled with anthropogenic stressors creates an imperative to characterize existing background conditions and drivers. In the present study, we examined the relative importance of facultative feeding and the role this plays in maintaining trophic consistency across a broad geographic region. This study will provide a baseline for future assessments of benthic structural integrity under changing local and global habitat conditions.

Trophic structure in the Strait of Georgia sediments varies little over a wide range of depths (0-678 m) and substrate types $(0.1-100 \%$ fines). Current regimes (Hill et al. 2008) and organic flux and quality conditions (Burd et al. 2008a) also vary considerably. Because we based our analyses on proportional organic biomass, trophic function also tends to be stable throughout a remarkable spectrum of total organic biomass, total production (B. J. Burd et al. unpubl. data) and taxonomic diversity (Burd et al. 2008a,b, 2009, Macdonald et al. 2010) in macrobenthic communities.

Gaston \& Nasci (1988) also found trophic structure to be resilient to natural shifts in abundance and biomass of dominant species and taxa. In the Strait of Georgia, such changes can be profound. For example, some of the most ubiquitous and dominant taxa in the Strait are small, facultative, detritivorous bivalves such as Axinopsida serricata, Macoma carlottensis and Acila castrensis. These and all other bivalves decline precipitously below $120 \mathrm{~m}$ and largely disappear below $200 \mathrm{~m}$ (Burd et al. 2008a; possible reasons for this decline are discussed therein). Despite the loss of this major taxonomic group in deep locations, trophic structure remains consistent, suggesting that other taxa fill the feeding niches vacated by these dominant bivalves.

An important question arises: how do benthic communities maintain consistent trophic structure and function in the face of continually shifting habitat conditions and sometimes dramatic population shifts? Clearly, facultative feeding is a crucial component of trophic stability of marine benthos. The most ubiquitous and typically dominant taxa in the Strait are facultative feeders, and the proportional biomass of the 2 major facultative feeding groups (detritivores and carnivores) varies little over the range of depths and substrate types examined in the present study. It is the ubiquity of these facultatively feeding taxa that drives trophic consistency throughout the Strait.
The dominance of taxa exhibiting facultative feeding noted in the Strait of Georgia benthos makes it difficult to discern the subtleties of trophic function in different habitats, given that we do not know which feeding mode a given facultative taxon may use under a specific set of habitat conditions. Nor do we know whether these facultative taxa exhibit broadscale biases towards a particular feeding mode over broad geographic areas, or switch their feeding mode continuously based on a response to smallscale local conditions (e.g. current, rate of food input; Dauer et al. 1981, Taghon et al. 1980). Understanding these subtleties is beyond the scope of the present study, but does point out the importance of studying feeding behaviour in these ubiquitous taxa.

Mallela \& Harrod (2008) suggested that stable isotope studies may reveal geographic variation in the food source(s) of facultative taxa. Studies of withinspecies isotopic variation in widespread and ubiquitous taxa in the Strait of Georgia may clarify the spatio-temporal scales of trophic function over different habitat types. We suggest that such studies are crucial for understanding organic carbon cycling in marine sediments, which store large amounts of the earth's carbon.

Although the dominant facultative feeders are responsible for the overall trophic consistency in the Strait of Georgia, many strict niche-feeding organisms respond to gradients in both depth and substrate type (Fig. 3), resulting in subtle trophic variation. In particular, trophic structure is significantly distinct in the coarse, shallow sediments $(<10 \%$ fines and $<25 \mathrm{~m}$ ) (see also Kennish et al. 2004). In these samples, macro-omnivores, herbivores and benthic carnivores make up a greater proportion of biomass than in deeper, coarser sediments. Therefore, despite the fact that facultative feeders dominate in shallow, coarse sediments, trophic composition varies more than in the other subtidal habitats. Chardy \& Clavier (1988), García-Arberas \& Rallo (2002) and Dolbeth et al. (2009) agree that the proportion of feeding types is more balanced in coarse sands. This phenomenon is often attributed to the higher diversity of microhabitats in coarse sediments (Carrasco \& Carbajal 1998, Muniz \& Pires 1999). In addition, herbivores and macro-omnivores both likely rely on the greater availability of algal food sources in the photic zone.

Suspensivores are also typically considered to be important in shallow, coarse sediments. However, we found few strict suspensivores (e.g. Porifera, Ascidiacea) in subtidal sediments, although they tend to be important on hard substrates (e.g. Ricciardi \& Bourget 1999, Gili \& Coma 1998). Most of the remaining 
subtidal taxa that suspension feed in the Strait of Georgia tend to deposit feed as well, thus allowing a greater depth and substrate distribution than strict suspensivores.

The third most dominant trophic group, the subsurface deposit feeders, are the only major trophic group (with $>10 \%$ total organic biomass) whose proportional biomass shows a clear, positive linear response to both depth and percent fines (Fig. 3, Table 3). However, these habitat variables explained only a modest amount of variability in proportional biomass of this trophic group (22\%). Although we cannot easily separate the effects of depth and substrate type (see Snelgrove \& Butman 1994), it is clear subsurface deposit feeders responded consistently and significantly to physical characteristics of the habitat.

There are a few possible reasons for the dominance of subsurface deposit feeders in deep samples with fine sediments. For instance, the large burrowing echinoderms Molpadia intermedia and Brisaster latifrons are slow-growing and long-lived, with low metabolic rates. Thus they may be resilient to temporal patchiness of food in deep locations. Additionally, large subsurface depositfeeders may be restricted to fine sediments characteristic of deep locations. These sediments are likely more cohesive than shallow, coarser sediments because of their high percentage fine grain (particularly clay) content (Sakamaki \& Nishimura 2007). The cohesion of fine sediments may be necessary for these animals to maintain the integrity of their burrows during feeding andirrigation. Capitellid worms and burrowing holothurians may also tolerate low sediment oxygen conditions common in deep areas because their respiratory appendages often protrude above the sediments in which they are feeding. In fact, previous work correlated the abundance of surface and subsurface deposit feeders negatively with bottom water oxygen content (García-Arberas \& Rallo 2002).

The tolerance of sub-surface deposit feeders to more extreme habitat conditions helps to explain why capitellids in particular often proliferate under conditions of elevated carbon loading, where sediment oxygen conditions may be low and other species are less able to compete (e.g. Pearson \& Rosenberg 1978, Weston 1990, Gaston et al. 1998, Mucha \& Costa 1999). However, not all subsurface deposit feeders perform similar functions in the environment. The large size range in this group of animals suggests high variation in their potential for bioirrigation and bioturbation of sediments. Therefore, although trophic structure tends to remain consistent over many habitat types, the size structure of communities, sediment mixing, and geochemistry may not.
This study encompasses habitats that vary widely in depth and sediment type, but also organic flux, quality of the organic material and current regime (Burd et al. 2008a, b, Hill et al. 2008). Although our analysis ignores seasonality and temporal variability, the consistency of trophic structure is striking considering the extent of habitat types represented (e.g. coarse, shallow sediments to deep, fine muds). Moreover, we expect that the spatial variation in community composition over the broad range of habitat types in this region greatly outweighs temporal variation for a given location in which habitat remains constant. The variation in trophic structure that does exist is explained almost entirely by the distribution of particular trophic groups that occupy specific feeding niches and are, therefore, more responsive to changes in habitat than facultative feeders.

\section{CONCLUSIONS}

The database upon which this study is based is the first of its kind on the west coast of Canada. We used this database to assess quantitatively the contribution of strict niche feeders versus facultative feeders to overall trophic structure across a broad range of water depths and sediment types in the Strait of Georgia. In this coastal inland sea, facultative feeders dominate biomass in all sediment habitats, and make up a remarkably consistent proportion of the total organic biomass in communities, regardless of habitat type. The most abundant and ubiquitous taxa in the Strait belong to these facultative feeding groups. The ability of these dominant facultative feeders to switch feeding modes explains the resilience and stability of trophic function in macrobenthic sediment communities over a wide range of habitat types and depths in the Strait of Georgia, and likely has implications for stability of trophic function in areas of anthropogenic discharges and other stressors. Trophic structure does not generally vary $>30 \%$ among all habitats, and what variation exists is explained by 2 factors: (1) the distinct nature of shallow, sandy fauna, and (2) significant gradient responses of subsurface deposit feeders to depth and substrate type below $25 \mathrm{~m}$ depth.

Acknowledgements. Funding for this work was provided by Fisheries and Oceans Canada and Metro Vancouver (formerly the Greater Vancouver Regional District) in support of the collaborative Ambient Monitoring Project (AMP). The authors thank two anonymous reviewers for contributing to the significant improvement of this manuscript. 


\section{LITERATURE CITED}

Albano MJ, Obenat SM (2009) Assemblage of benthic macrofauna in the aggregates of the tubiculous worm Phyllochaetopterus socialis in the Mar del Plata harbour, Argentina. J Mar Biol Assoc UK 89:1099-1108

> Aller RC, Yingst Y (1985) Effects of the marine deposit-feeders Heteromastus filiformis (Polychaeta), Macoma baltica (Bivalvia), and Tellina texana (Bivalvia) on averaged sedimentary solute transport, reaction rates and microbial distributions. J Mar Res 43:615-645

Bergmann M, Dannheim J, Bauerfeind E, Klages M (2009) Trophic relationships along a bathymetric gradient at the deep-sea observatory HAUSGARTEN. Deep-Sea Res I 56:408-424

Bray JR, Curtis JT (1957) An ordination of the upland forest communities of southern Wisconsin. Ecol Monogr 27: 325-349

Brey T (2001) Population dynamics in benthic invertebrates. A virtual handbook. Alfred Wegener Institute for Polar and Marine Research, Germany, available at www.awibremerhaven.de/Benthic/Ecosystem/FoodWeb/Hand book/main.html

Brown SS, Gaston GR, Rakocinski CF, Heard RW (2000) Effects of sediment contaminants and environmental gradients on macrobenthic community trophic structure in Gulf of Mexico estuaries. Estuaries 23:411-424

> Burd BJ, Macdonald RW, Johannessen SC, van Roodselaar A (2008a) Responses of subtidal benthos of the Strait of Georgia, British Columbia, Canada to ambient sediment conditions and natural and anthropogenic depositions. Mar Environ Res 66:S62-S79

Burd BJ, Barnes PAG, Wright CA, Thomson RE (2008b) A review of subtidal benthic habitats and invertebrate biota of the Strait of Georgia, British Columbia. Mar Environ Res 66:S3-S38

Burd BJ, McGreer E, Taekema B, Macdonald TA (2009) Utility of large regional databases for understanding abundance and diversity characteristics of natural marine soft substrate fauna. Can Tech Rep Fish Aquat Sci 2859: $1-121$

> Busby TO, Plante CJ (2007) Deposit feeding during tidal emersion by the suspension-feeding polychaete, Mesochaetopterus taylori. Southeast Nat 6:351-358

> Cacabelos E, Dominguez M, Troncoso JS (2009) Trophic structure of soft-bottom macrobenthos in an inlet in north-western Spain. J Mar Biol Assoc UK 89:439-447

> Cadée GC (1984) 'Opportunistic feeding', a serious pitfall in trophic structure analysis of (paleo)faunas. Lethaia 17: 289-292

> Carrasco FD, Carbajal W (1998) The distribution of polychaete feeding guilds in organic enriched sediments of San Vincente Bay, Central Chile. Int Rev Hydrobiol 83: 233-249

- Chardy P, Clavier J (1988) Biomass and trophic structure of macrobenthos in the south-west lagoon of New Caledonia. Mar Biol 99:195-202

Clarke KR, Gorley RN (2006) PRIMER v6: user manual/tutorial. PRIMER-E, Plymouth

Clarke KR, Warwick RM (2001) Change in marine communities: an approach to statistical analysis and interpretation, 2nd edn. PRIMER-E, Plymouth

Coyle K, Konar B, Blanchard A, Highsmith RC and others (2007) Potential effects of temperature on the benthic infaunal community on the southeastern Bering Sea shelf: possible impacts of climate change. Deep-Sea Res II 54:2885-2905

Dauer DM, Maybury CA, Ewing RM (1981) Feeding behaviour and general ecology of several spionid polychaetes from the Chesapeake Bay. J Exp Mar Biol Ecol 54:21-38

Desrosiers G, Savenkoff C, Olivier M, Stora G and others (2000) Trophic stucture of macrobenthos in the Gulf of St. Lawrence and on the Scoian Shelf. Deep-Sea Res II 47: 663-697

> Dolbeth M, Teixeira H, Marques JC, Pardal MA (2009) Feeding guild composition of a macrobenthic subtidal community along a depth gradient. Sci Mar 73:225-237

> Dufour SC, Felbeck H (2006) Symbiont abundance in thyasirids (Bivalvia) is related to particulate food and sulphide availability. Mar Ecol Prog Ser 320:185-194

Fauchald K, Jumars P (1979) Diet of worms: a study of polychaete feeding guilds. Oceanogr Mar Biol Annu Rev 17: 193-284

García-Arberas L, Rallo A (2002) The intertidal soft-bottom infaunal macrobenthos in three Basque estuaries (Gulf of Biscay): a feeding guild approach. Hydrobiologia 475/476:457-468

> Gaston GR, Nasci JC (1988) Trophic structure of macrobenthic communities in the Calcasieu estuary, Louisiana. Estuaries 11:201-211

Gaston GR, Bartlett JHW, McAllister AP, Heard RW (1996) Biomass variations of estuarine macrobenthos preserved in ethanol and formalin. Estuaries 19:674-679

Gaston GR, Rakocinski CF, Brown SS, Cleveland CM (1998) Trophic function in estuaries: response of macrobenthos to natural and contaminant gradients. Mar Freshw Res 49:833-846

Gaudencio MJ, Cabral HN (2007) Trophic structure of macrobenthos in the Tagus estuary and adjacent coastal shelf. Hydrobiologia 587:241-251

Gili JM, Coma R (1998) Benthic suspension feeders: their paramount role in littorial marine food webs. Trends Ecol Evol 13:316-321

Gray JS (1981) The ecology of marine sediments. An introduction to the structure and function of benthic communities. Cambridge University Press, Cambridge

Gray JS, Elliott M (2009) The ecology of marine sediments. From science to management. Oxford University Press, Oxford

Hill PR, Conway K, Lintern DG, Meulé S, Picard K, Barrie JV (2008) Sedimentary processes and sediment dispersal in the southern Strait of Georgia, BC, Canada. Mar Environ Res 66 (Suppl):S39-S48

Johannessen SC, Macdonald RW, Burd B, van Roodselaar A (2008) Biogeochemical cycling in the Strait of Georgia. Mar Environ Res 66 (Suppl):S1-S2

Kennish MJ, Haag SM, Sakowicz GP, Durand JB (2004) Benthic macrofaunal community structure along a welldefined salinity gradient in the Mullica River - Great Bay Estuary. J Coast Res 45:209-226

> Levinton J (1972) Stability and trophic structure in depositfeeding and suspension-feeding communities. Am Nat 106:472-486

Levinton JS (1991) Variable feeding behaviour in three species of Macoma (Bivalvia, Tellinacea) as a response to water flow and sediment transport. Mar Biol 110: 375-383

Levinton J, Kelaher B (2004) Opposing organizing forces of deposit-feeding marine communities. J Exp Mar Biol Ecol 300:65-82 
Macdonald TA, Burd B, Macdonald VI, van Roodselaar A (2010) Taxonomic and feeding guild classification for the marine benthic macroinvertebrates of the Strait of Georgia, British Columbia. Can Tech Rep Fish Aquat Sci 2874:1-63

Mallela J, Harrod C (2008) $\delta^{13} \mathrm{C}$ and $\delta^{15} \mathrm{~N}$ reveal significant differences in the coastal foodwebs of the seas surrounding Trinidad and Tobago. Mar Ecol Prog Ser 368:41-51

Mucha AP, Costa MH (1999) Macrozoobenthic community structure in two Portuguese estuaries: Relationship with organic enrichment and nutrient gradients. Acta Oecol 20:363-376

Muniz P, Pires AMS (1999) Trophic structure of polychaetes in the Sao Sebastiao Channel (southeastern Brazil). Mar Biol 134:517-528

Nemec AFL, Brinkhurst RO (1988) Using the bootstrap to assess statistical significance in the cluster analysis of species abundance data. Can J Fish Aquat Sci 45:965-970

Okamura B (1990) Behavioural plasticity in the suspension feeding of benthic animals. In: Hughes RN (ed.) Behavioural mechanism of food selection. Springer, Berlin, p 637-660

Pearson TH (2001) Functional group ecology in soft-sediment marine benthos: the role of bioturbation. Oceanog Mar Biol Ann Rev 39:233-267

Pearson TH, Rosenberg R (1978) Macrobenthic succession in relation to organic enrichment and pollution of the marine environment. Oceanogr Mar Biol Ann Rev 16: 229-311

Pearson TH, Rosenberg R (1987) Feast and famine: structuring factors in marine benthic communities. In: Gee JHR, Giller PS (eds.) Organization of communities: past and present. Blackwell, Oxford, p 373-395

Pohlo R (1969) Confusion concerning deposit feeding in the Tellinacea. J Molluscan Stud 38:361-363

- Rakocinski CF, Brown SS, Gaston GR, Heard RW, Walker WW, Summers JK (1997) Macrobenthic responses to natural and contaminant-related gradients in northern Gulf of Mexico estuaries. Ecol Appl 7:1278-1298

Rhoads DC (1974) Organism-sediment relations on the muddy sea floor. Oceanogr Mar Bio Ann Rev 12:263-300

Rhoads DC, Young DK (1970) Influence of deposit-feeding organisms on sediment stability and community trophic structure. J Mar Res 28:150-178

Editorial responsibility: Paul Snelgrove, St. John's, Newfoundland and Labrador, Canada
Ricciardi A, Bourget E (1999) Global patterns of macroinvertebrate biomass in marine intertidal communities. Mar Ecol Prog Ser 185:21-35

Rossi F, Herman PMJ, Middelburg JJ (2004) Interspecific and instraspecific variation of $\delta^{13} \mathrm{C}$ and $\delta^{15} \mathrm{~N}$ in depositand suspension-feeding bivalves (Macoma balthica and Cerastoderma edule): Evidence of ontogenetic changes in feeding mode of Macoma balthica. Limnol Oceanogr 49:408-414

Saiz-Salinas JI, Ramos A (1999) Biomass size-spectra of macrobenthic assemblages along water depth in Antarctica. Mar Ecol Prog Ser 178:221-227

Sakamaki T, Nishimura O (2007) Physical control of sediment carbon content in an estuarine tidal flat system (Nanakita River, Japan): a mechanistic case study. Estuar Coast Shelf Sci 73:781-791

Sanders HL (1958) Benthic studies in Buzzards Bay. I. Animal-sediment relationships. Limnol Oceanogr 3:245-258

Sneath PHA, Sokal RR (1973) Numerical taxonomy. Freeman, San Francisco, CA

Snelgrove PVR, Butman CA (1994) Animal sediment relationships revisited - cause versus effect. Oceanogr Mar Biol Annu Rev 32:111-177

Taghon GL, Nowell ARM, Jumars PA (1980) Induction of suspension feeding in spionid polychaetes by high particulate fluxes. Science 210:562-564

van Oevelen D, Soetaert K, Middelburg JJ, Herman PMJ and others (2006) Carbon flows through a benthic food web: integrating biomass, isotope and tracer data. J Sea Res 64:453-482

Wessa P (2011) Multiple Regression Software (C Module). Office for Research Development and Education, version 1.1.23-r6, available at www.wessa.net/

Weston DP (1990) Quantitative examination of macrobenthic community changes along an organic enrichment gradient. Mar Ecol Prog Ser 61:233-244

Wetzel MA, Leuchs H, Koop JHE (2005) Preservation effects on wet weight, dry weight, and ash-free dry weight biomass estimates of four common estuarine macro-invertebrates: no difference between ethanol and formalin. Helgol Mar Res 59:206-213

Word JQ (1990) The infaunal trophic index, a functional approach to benthic community analyses. PhD dissertation, University of Washington, Seattle, WA

Submitted: June 14, 2010; Accepted: November 3, 2011

Proofs received from author(s): January 5, 2012 